\title{
Explicitly salinity and sediment concentration on flocculation processes in estuaries
}

\author{
A. Mhashhash; B. Bockelmann-Evans and S. Pan \\ School of Engineering, Cardiff University, mhashhashAF1@cardiff.ac.uk
}

ABSTRACT: Cohesive sediment is generally able to flocculate and create flocs, which are larger than individual particles and less dense. The phenomenon of flocculation has an important role in sediment transport processes of settling, deposition, and erosion. In this study, well controlled laboratory experiments were performed to investigate the effect of key hydrodynamic parameters: suspended sediment concentration (c) and salinity (S) on floc size and settling velocity. Experimental research was conducted in a $1 \mathrm{~L}$ glass beaker of 11 $\mathrm{cm}$ diameter using suspended sediment samples from the Severn Estuary. A PIV system and image processing routine were used to measure the floc size distribution and settling velocity. This study found that the flocculation is enhanced with increasing sediment concentration but not with increasing salinity. The settling velocity was found to range from 0.2 and $1.2 \mathrm{~mm} / \mathrm{s}$. Settling velocity changed in the case of increasing suspended sediment concentration (SSC) was controlled by the value of salinity. The faster settling velocity rates occurred for the higher concentrations, as well as for low salinities of S $2.5 \mathrm{ppt}$. On the other hand, at high salinity of $20 \mathrm{ppt}$ alongside increasing c, the situation was reversed, i.e., the lower the sediment concentration the faster the settling velocity, was found.

InTroduction

Cohesive sediments are regarded as one of the most important features of estuaries around the world.

The sediment size of the cohesive sediment is normally in a range of 2- $63 \mu \mathrm{m}$. Under certain conditions, these sediments flocculate to form large aggregates, namely flocs, which are larger than individual particles but less dense. This flocculation phenomenon has a strong influence on the sediment transport processes of deposition, erosion and settling (Fennessy et al. 1994).

In general, flocs were classified as two types, namely, microflocs and macroflocs, whereas cohesive sediment flocculates to form small microflocs first, and then macroflocs by combining the microflocs (Eisma 1986). Microflocs can be classified as those aggregates which do not exceed a spherically equivalent diameter of $160 \mu \mathrm{m}$ and have a settling velocity of less than $1 \mathrm{~mm} / \mathrm{s}$. The state of microflocs continually changes in response to the hydrodynamic parameters, and the physico-chemical and environmental conditions. These microflocs can develop into larger flocs called macroflocs which behave very differently. Macroflocs have a diameter larger than $160 \mu \mathrm{m}$ and a settling velocity between 1-15 $\mathrm{mm} / \mathrm{s}$ (Fennessy et al. 1994; Manning and Dyer 1999; Manning 2001; Manning et al. 2013).
The flocculation process mainly occurs in the very low salinity region (between 1 and $2.5 \mathrm{ppt}$ ) (Wollast 1988), and it is affected by hydrodynamical changes which can alter the suspended sediment particle by modifying its effective particle size, shape, porosity, density and composition. Numerous studies have been carried out to investigate the flocculation phenomenon in the lab, such as (Serra et al. 1997; Manning and Dyer 1999; Mikes et al. 2004; Maggi 2005). Due to the complexity of the natural system, many simplifications are made in laboratory studies in order to control the different variable parameters in the flocculation process. One of the main parameters for studying the flocculation process in the lab is the turbulent agitator, which is used with the aim to create conditions as close to the natural estuarine environment as possible.

Four different devices, namely the jar test (Mikes et al. 2004), annular flume (Dyer and Manning 1999), sedimentation column and turbulence grid (Maggi 2005), and the Couette device with a video camera system (Serra et al. 1997; Serra and Casamitjana 1998) have been used for generating turbulence and flocculation in the lab. A laboratory video analysis method was developed to measure the 
size of the flocs. This instrumental set-up requires little equipment and is easy to implement in the laboratory. It consists of a glass bowl, CCD camera and variable speed agitator control for the turbulent level inside the bowl. The floc size can then be measured under varying turbulent conditions.

The aim of this study is to determine the effect of increasing suspended sediment concentration (SSC) alongside salinity on the flocculation phenomenon. Floc size and settling velocities were measured during these experiments.

\section{MATERIALS AND METHODS}

\subsection{Overview of study area}

The Severn Estuary, located between South East Wales and South West England, is the largest tidal river in the $\mathrm{UK}$ and has the third highest tidal range in the world with a spring tide of up to $14.7 \mathrm{~m}$ (Kadiri 2014). The estuary generates high currents that exceed 3m/s (Gao et al. 2011). The river system has a total catchment area of approximately $25,000 \mathrm{~km}^{2}$ (Jonas and Millward 2010) and the estuary has a total channel length of $137 \mathrm{~km}$. The major tributaries of the Severn are the Usk, Wye (on the Welsh side) and the Stour (on the English side). The tidal range varies significantly along the estuary and over time and the average spring and neap tidal ranges are $12.3 \mathrm{~m}$ and $6.5 \mathrm{~m}$, respectively (Kirby 2010). The annual suspended sediment load has been approximated at $1.6 \times 10^{9} \mathrm{~kg} /$ year; nearly $1.25 \times 10^{9} \mathrm{~kg} /$ year of which is discharged from the rivers Wye, Avon and Severn (McLaren et al. 1993).

Flocculation phenomenon was studied in the laboratory with 1L glass beaker and a Particle Image Velocimetry (PIV) system using suspended sediment from the Severn Estuary. Samples were collected from 'Slipway' in proximity of the New Severn Bridge as shown in Figure 1.

\subsection{Instrumentation}

Flocculation experiments were conducted in $1 \mathrm{~L}$ glass beaker of $11 \mathrm{~cm}$ diameter. It was equipped with a variable speed agitator to control turbulence of the flow inside the beaker. A settling column with a diameter of $5 \mathrm{~cm}$ and a height of $40 \mathrm{~cm}$ was used to measure the flocs' settling velocities. Flocs were introduced from the top of the settling column filled with water, where the falling flocs were filmed using a PIV system as shown in Figure 2. The PIV system consists of a backlight which is positioned opposite the CCD camera to provide a uniform black background upon which particles appear as white, the CCD camera with 1392 X1040 pixel sensitivity, fo- cal length, $\mathrm{f}$, of $9 \mathrm{~mm}$ and a maximum frequency of 30 fps $(\Delta \mathrm{t}=1 / 30 \mathrm{~s})$, a Polytec BVS-11 Wotan flash stroboscope and trigger box, fibre optic cable and linelight.

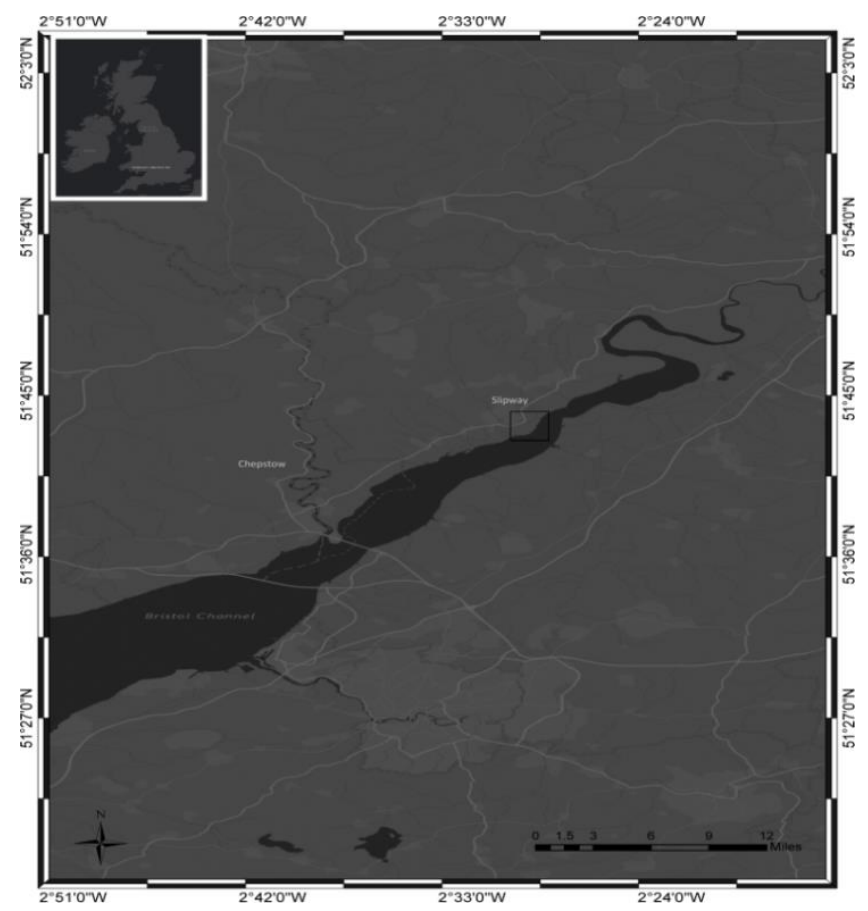

Figure 1 Map of Severn Estuary showing the location of sampling sites, Slipway ( $\left.2^{\circ} 300^{`} 00.67^{\prime \prime} \mathrm{N}, 51^{\circ} 42^{`} 52.12^{\prime \prime} \mathrm{W}\right)$.

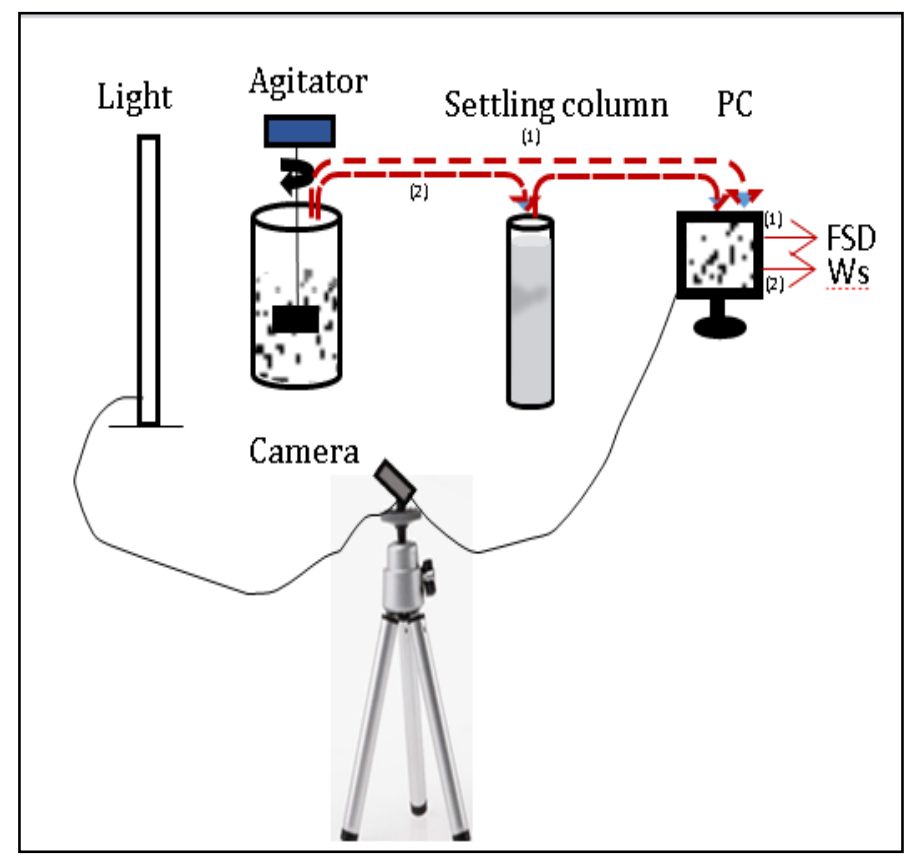

Figure 2 Schematic diagram of PIV system, settling column, sample bowl and stirrer.

\subsection{Experimental procedures}

Natural flocculation processes are difficult to be reproduced in laboratory experiments due to the complexity of processes involved. However, the laboratory experiments are valuable for investigating systematically the effect of specific parameters such 
as salinity, suspended sediment concentration and turbulence under controlled conditions (Manning 2004; Manning et al. 2004; Mikes et al. 2004). This study focuses on the influence of suspended sediment concentration (SSC) alongside salinity on the floc size and settling velocity.

The experimental method consists of two main steps: The first step is to apply the highest tested shear stress of $60 \mathrm{~N} / \mathrm{m}^{2}$ to break down any potential macroflocs in suspension as the initial state; the second step, which is the main part of the tests, whereas the agitator is settled to the lowest turbulent level of $0.57 \mathrm{~N} / \mathrm{m}^{2}$ for a duration of $120 \mathrm{~min}$ as suggested by (Mikes et al. 2004; Verney et al. 2009), which is the significant time period for flocculation to occur in natural water bodies (Le Hir et al. 2001). During the experiment, a series of images is recorded from the PIV system at different time steps in order to calculate the floc size distributions over the investigated period.

To eliminate the effect of sediment concentration variation on flocs size and settling velocity a set of laboratory experiments with suspended sediment concentration (SSC) of 100, 150 and $200 \mathrm{mg} / \mathrm{l}$ were conducted at two different salinities of $S=2.5 \mathrm{ppt}$ and $\mathrm{S}=20 \mathrm{ppt}$ and at a low turbulent level of $\eta=0.57$ $\mathrm{N} / \mathrm{m}^{2}$. This value of turbulent level was chosen in this experiment because it was considered to be the represent optimum conditions for flocculation processes. For each test, $10 \mathrm{ml}$ of flocculated sample was then introduced from the top of the settling column. After introduction of the sample into the water column, the flocs were allowed to settle by gravity over a distance of approximately $13 \mathrm{~cm}$ prior to switching the camera on and in order to allow the damping out of any activity from the introduction method.

\subsection{Analyses}

The floc size distribution and settling velocity were both obtained from floc image recording and processing. The main five steps in the image processing are: (1) selection of the flocs manually at the start and at the end of the sequence by opening images using image editor and paint program; (2) enhancing background (brightness and contrast); (3) removing any noise to make sure the flocs appear in all of the sequential images by opening images using an image editor and the paint program; (4) removing all flocs which are touching the image boundary and are not in focus; and (5) calculating the features of flocs including: sectional area, location and circularity by using the "imageJ" software. As this method is interactive there is very low risk of errors being made in the determination of the floc paths.

ImageJ was used to detect particles larger than 70 $\mu \mathrm{m}$ below this limit the pixel resolution of the floc measurement is not consistent and hence the small- est microflocs are not accounted for the description of the floc population during the experiment. Floc size was obtained using the contrast between the dark background and the white silhouettes of the floc. The surface equivalent diameter $d$ was calculated by converted particle area (A) into equivalent circular diameter (Flory et al. 2004; Mikes et al. 2004; Verney et al. 2009) as

$d=\sqrt{\frac{4 \mathrm{~A}}{\pi}}$

\section{RESULTS AND DISCUSSION}

This section describes the laboratory experiments results of the combined influence of sediment concentration and salinity on flocs size distribution (FSD) and their settling velocity.

\subsection{Floc size distribution (FSD)}

The floc size distributions as a function of SSC (100, 150 , and 200) $\mathrm{mg} / \mathrm{l}$ at both salinity ranges of 2.5 and 20 ppt are displayed in Figure 3 A, B. Table 1 shows the eight bands of size distributions which were used in this study based on the floc size. Band 1 represents flocs with a size of less than $100 \mu \mathrm{m}$, whilst band 8 represents flocs with a size bigger than 700 $\mu \mathrm{m}$ and bands 2 to 7 the size ranges in between. Floc size Floc size exhibits variability that increases with increasing SSC at both salinity ranges of 2.5 and 20 ppt Figure $3 \mathrm{~A}$ and $\mathrm{B}$. The floc size distribution for the data shows that particle sizes ranged from $75 \mu \mathrm{m}$ (detection limit) to $800 \mu \mathrm{m}$, with the greatest floc area in the size of $150-250 \mu \mathrm{m}$. Figure $3 \mathrm{~A}$ and B indicates that floc size decreases with increasing salinity from $2.5 \mathrm{ppt}$ to $20 \mathrm{ppt}$ at sediment concentration of $100 \mathrm{mg} / \mathrm{l}$. This result is in a good agreement with previous studies. Dobereiner and McManus (1983) found that coagulation increases at low salinities (12) ppt based on data from the Tay Estuary. Also, Gibbs and Konwar (1986) found that aggregate size in the Amazon Shelf depended on the salinity when it was less than 10ppt. Wollast (1988) found that intense flocculation occurs as soon as salinity increases to about 1ppt and is complete when salinities have reached values above 2.5 ppt. Krone (1962); Allersma (1967); MIGNIOT (1968); Lintern (2003); THILL ( 2001) show that the salinity variation affects flocculation through a threshold action upward from which a further increase has no effect.

Moreover, the percentage of large flocs $(>700 \mu \mathrm{m})$ at S 2.5 ppt decreases from $9 \%$ to $2 \%$ with increasing concentrations from 100 to $200 \mathrm{mg} / \mathrm{l}$ as shown in Figure $3 \mathrm{~A}$. This result is in good agreement with the results obtained by (Manning and Dyer 1999), who 
worked at the Tamar Estuary with in situ settling velocity (INSSEV). It is discussed that this decreasing in the percentage of large floc with increasing sediment concentration could be a result of the disruption caused by collisions. In contrast, for S of $20 \mathrm{ppt}$, the percentage of large flocs increased with increasing concentration, presumably because of aggregation at low sediment concentration and high salinity of $20 \mathrm{ppt}$ is less than that at low sediment concentration and low salinity of $2.5 \mathrm{ppt}$. Considering the result shown in Figure 3 A and B a conceptual model was developed as shown in Figure 4
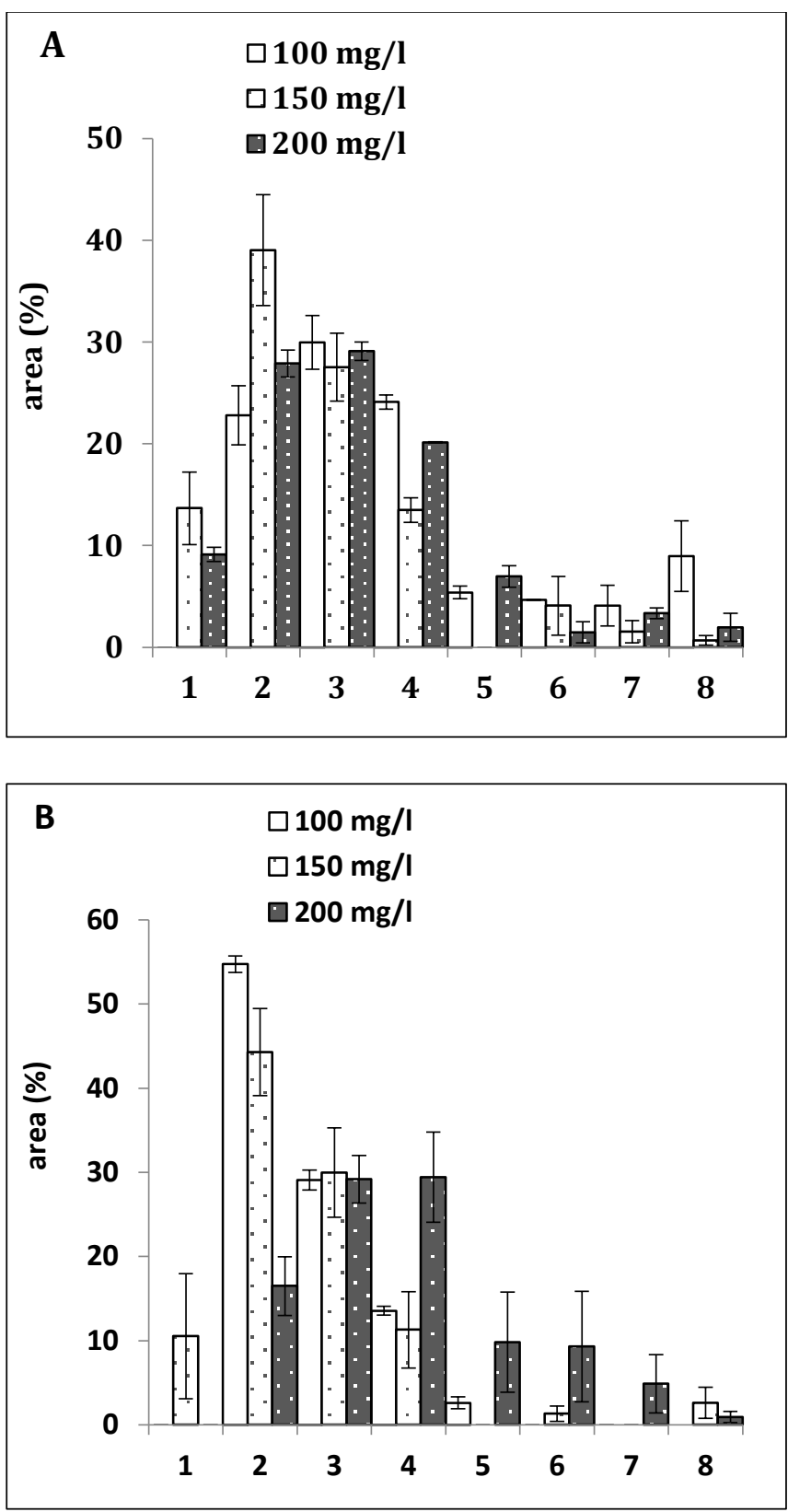

Figure 3 Floc size distribution at various concentration A) $\mathrm{S}=2.5 \mathrm{ppt}$, B) $\mathrm{S}=20 \mathrm{ppt}$, range including the standard deviation between two runs.

Table 1 The definition of floc size band

\begin{tabular}{llllllllll}
\hline $\begin{array}{l}\text { Size } \\
\text { band }\end{array}$ & 1 & 2 & 3 & 4 & 5 & 6 & 7 & 8 \\
\hline
\end{tabular}

Floc size < 100- 200- 300- 400- 500- 600- >

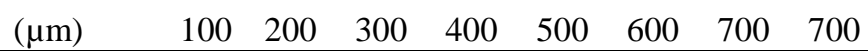

This model is based on the variation of the flocs' surface area related to their size depending on different salinity and suspended sediment concentrations. This conceptual model is characterized by two lines. The first line represents the optimum floc size and its percentage area at low sediment concentration and salinity, and at high sediment concentration and salinity. The second line presents the floc size and the percentage of the flocs' surface area at high sediment concentration and low salinity and at low sediment concentration and high salinity. The flocculation onset can occur at low salinity and low concentration. This is the best environment for floc size to reach the maximum size of more than $700 \mu \mathrm{m}$. With increasing concentrations, the flocs are more likely to bump into each other which subsequently cause the flocs' breakdown. In this situation the floc size is still larger than $700 \mu \mathrm{m}$ but the percentage of the flocs' surface area is decreased by $77 \%$ as can be seen in Figure $3 \mathrm{~A}$. When the salinity is increased from $2.5 \mathrm{ppt}$ to $20 \mathrm{ppt}$, particles don't exceed 500 $\mu \mathrm{m}$ at sediment concentrations of $100 \mathrm{mg} / \mathrm{l}$ as shown in Figure $3 \mathrm{~B}$. This stage might be transitory until a specific amount of sediment is attained, which gives particles a higher chance to attract each other and reach sizes in excess of $700 \mu \mathrm{m}$ at $\mathrm{C}$ of $200 \mathrm{mg} / \mathrm{l}$ (see Figure 3 B).

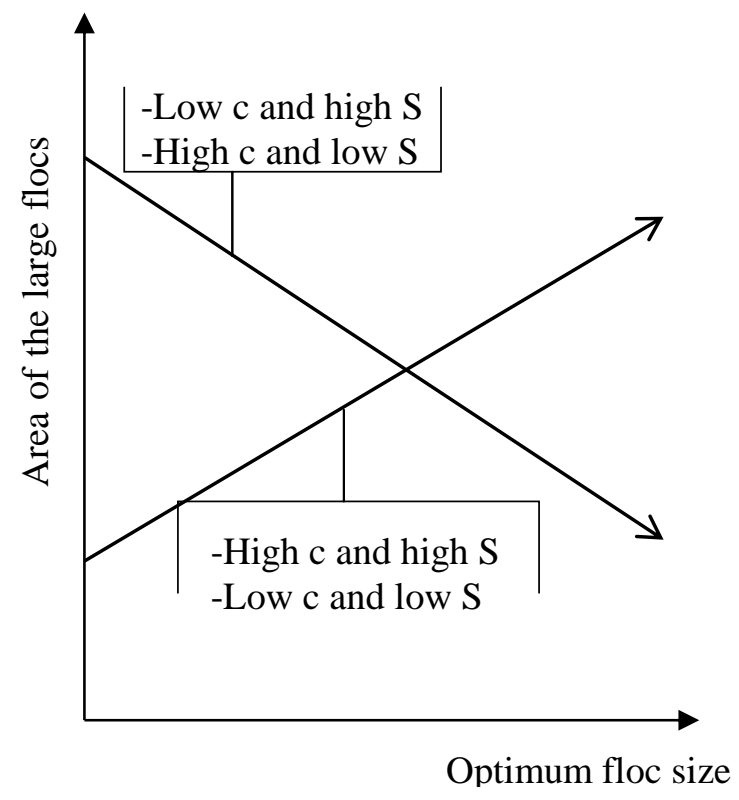

Figure 4 Schematic representation of the salinity and sediment concentration influence on the area and the size of the floc.

\subsection{Settling velocity}

The relationship between the average floc size and settling velocity for a specific suspended sediment concentration (SSC) for both salinity ranges of 2.5 and 20 ppt is shown in Figure 5 A and B. These graphs show that the settling velocity changes from 
0.4 to $1.2 \mathrm{~mm} . \mathrm{s}^{-1}$ and 0.2 to $1.1 \mathrm{~mm} . \mathrm{s}^{-1}$ for salinities of 2.5 and $20 \mathrm{ppt}$ respectively. Also, it can be seen in Figure $5 \mathrm{~A}$ that the faster settling velocity occurred for the higher concentration $(200 \mathrm{mg} / \mathrm{l})$ and lower salinity (2.5 ppt). This result was similar to findings from previous studies (Burban et al. 1989; Manning 2004) where it was also found for low shear stresses that the settling velocities were smaller at the lowest concentration and increasing with increasing concentrations.
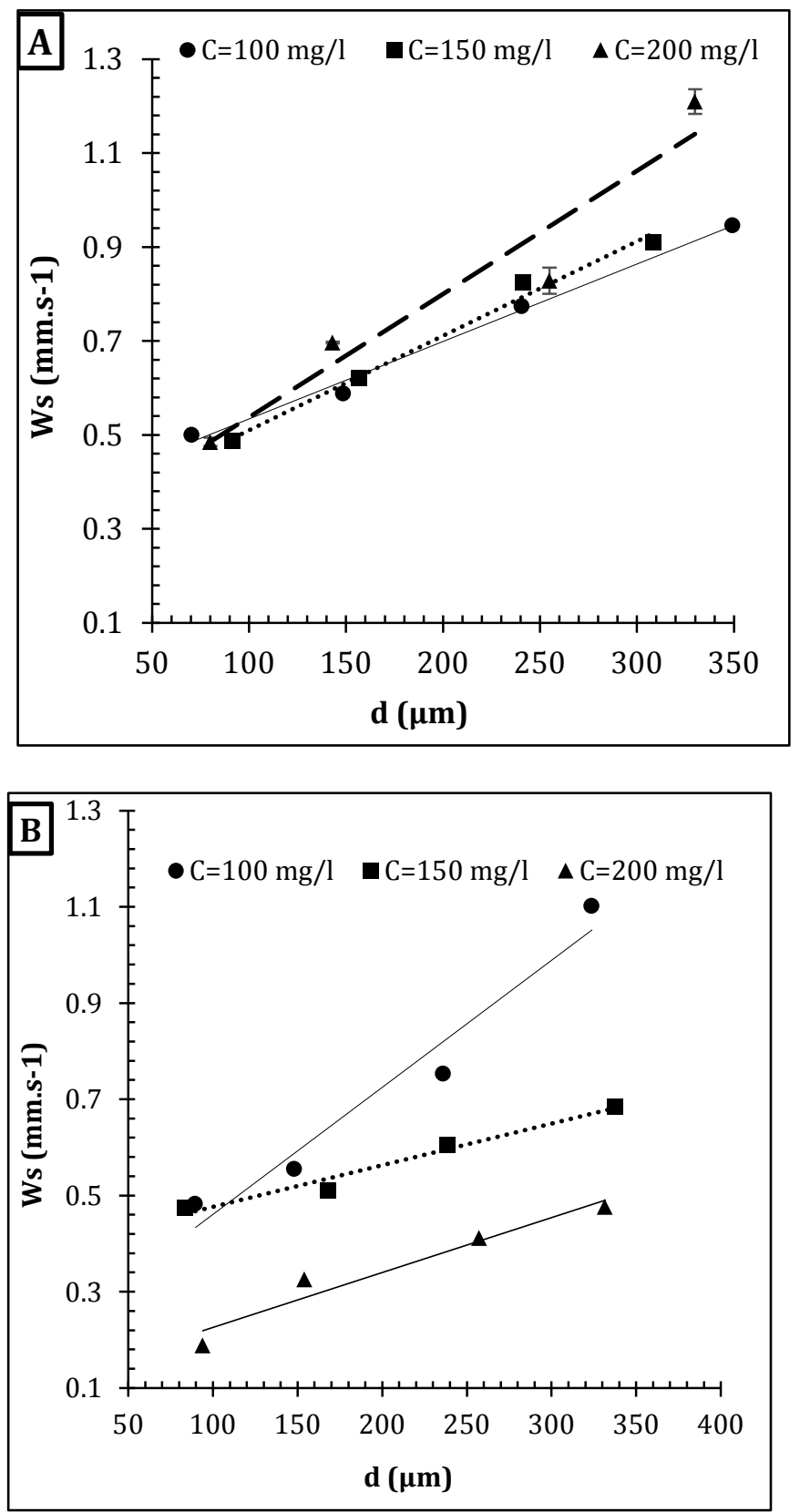

Figure 5 Settling velocity for various concentrations (different symbols) against floc size at A) $\mathrm{S}=2.5 \mathrm{ppt}$ and B).S=20ppt.

Also, Pejrup and Mikkelsen (2010) found that the settling velocity increases with increasing suspended sediment concentration from 20 to $200 \mathrm{mg} / \mathrm{l}$ under fresh water conditions. This result is based on data collected by (Pejrup et al. 1997) from Rømø Dyb. This can be explained as at high concentration and low salinity as discussed in Figure 4, the particles start bumping into each other which leads to a decrease of the flocs' surface area and to the floc become denser. Whereas, at high salinity of $20 \mathrm{ppt}$ the situation was found reversed and the faster settling velocity was found to occur at lower sediment concentrations. This could be result of the structure of the floc as shown in Figure 6, which represents SEM photographs of flocs at $S=20 \mathrm{ppt}$ and turbulence 0.57 $\mathrm{N} / \mathrm{m}^{2}$ for sediment concentrations of 100 and 200 $\mathrm{mg} / \mathrm{l}$. It can clearly be seen that the flocs at high sediment concentration $(200 \mathrm{mg} / \mathrm{l})$ become unstable and more fragile (less dense) as they grow. Therefore it was expected that the settling velocity decreased with increasing sediment concentration for this range of salinity $(20 \mathrm{ppt})$.

The Minitab 17 statistical package was used to model the experimental data and perform a multiple linear regression analysis. It was revealed that an equation that included the parameters of floc size and sediment concentration could represent the variation in the settling velocity. The linear equations are developed for salinities of 2.5 and $20 \mathrm{ppt}$ and shear stress of $0.57 \mathrm{~N} / \mathrm{m}^{2}$. The regression equations between aggregate size (in $\mu \mathrm{m}$ ) and concentration (in $\mathrm{g} / \mathrm{l}$ ) for $\mathrm{S}=2.5$ and $\mathrm{S}=20 \mathrm{ppt}$ respectively can be expressed as

$$
\begin{aligned}
& W_{S}=0.35-0.37 c+0.00127 d+0.006 c d \\
& W_{S}=0.36-0.84 c+0.00376 d+0.015 c d
\end{aligned}
$$
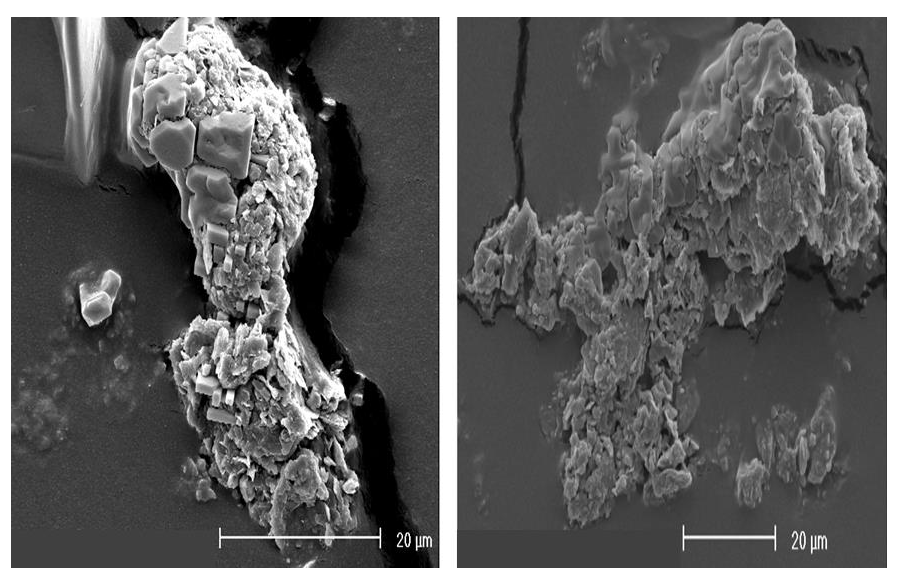

Figure 6 A selection of SEM photographs of flocs at $S=20$ ppt, different $\mathrm{c}, \mathrm{A}=100$ and $\mathrm{B}=200 \mathrm{mg} / \mathrm{l}$.

The units are: floc size in microns, settling velocity in $\mathrm{mm} / \mathrm{s}$ and concentration in $\mathrm{g} / \mathrm{l}$. The regression equations indicated that $93.27 \%$ and $97.52 \%$ from the variation in settling velocity for $\mathrm{S}$ of 2.5 and 20 ppt, respectively can be explained by the regression formulae (3) and (4). However, these results will be 
compared with in situ measurements and numerical model outputs before they can confidently be used in predictive models.

\subsection{Floc structure and density}

The floc structures are shown in Figure 6, which represents SEM photographs at two different sediment concentrations of $100 \mathrm{mg} / \mathrm{l}$ and $200 \mathrm{mg} / \mathrm{l}$. It cannot be directly measure the floc structure using PIV camera, the fractal dimension of flocs can be determined theoretically using Winterwerp model (Winterwerp 1999). This model was developed based on field and lab data, as shown in Figure 7. The experiment data of settling velocity and floc size at different sediment concentration and salinity was plotted with Winterwerp model in Figure 7. It is observed that the data match the Winterwerp model adequately. The overall trend of the experiment data points seems slightly steeper than the fit with $\mathrm{nf}=2$.

However, when the individual data set are studied, the slope agree better with nf between 2 and 2.3 for salinity $2.5 \mathrm{ppt}$, and $\mathrm{nf}$ between 1.7 and 2 for salinity 20 ppt. This result confirmed that the floc size become more irregular shape with increasing salinity ranges. It is important to work with $\mathrm{nf}$ value as the density is more realistic than the stokes law. As in the stokes law the density calculated is based on the assumption of the flocs have a spherical diameter. By known nf value from this chart, it will be easy to calculate the floc density from theoretical equation

$\rho_{f}-\rho_{w}=\left(\rho_{s}-\rho_{w}\right)\left(\frac{d^{n f-3}}{d_{i}}\right)$

Where $\rho_{\mathrm{f}}$ is the floc density, $\rho_{\mathrm{w}}$ is the water density, $\rho_{\mathrm{s}}$ is the mud density, $d$ is the equivalent spherical diameter, $d_{i}$ is the diameter of the primary particle and $\mathrm{n}_{\mathrm{f}}$ is the fractal dimension.

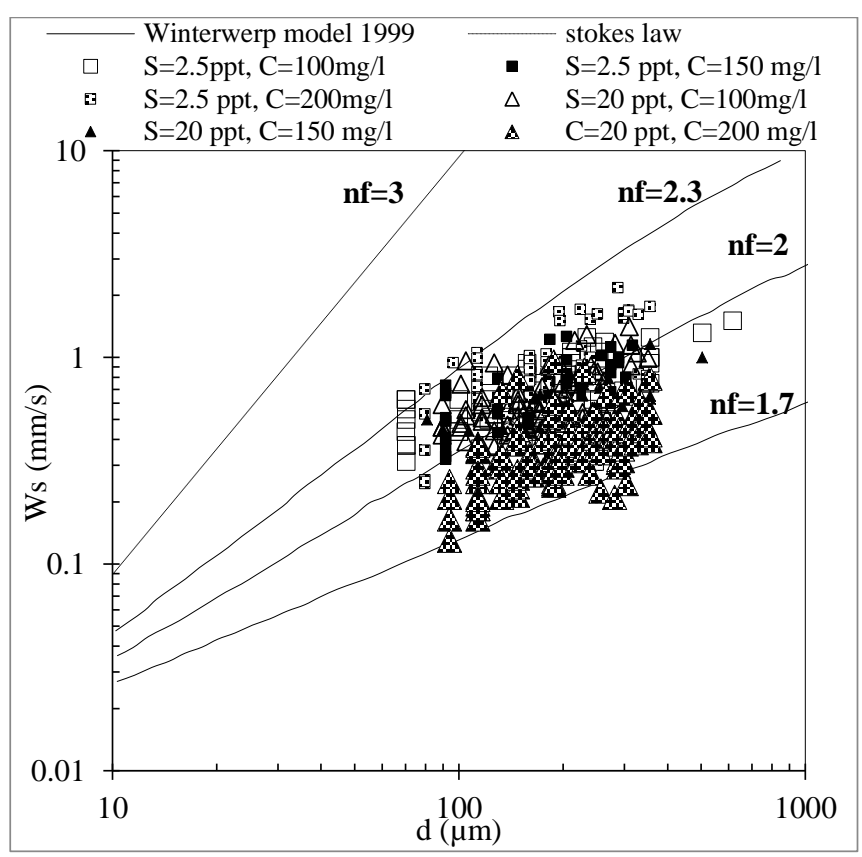

Figure 7 Relation between settling velocity and floc size

\section{CONCLUSIONS}

The potential impacts of the hydrodynamic parameters (i.e. salinity and suspended sediment concentration) on the floc size and settling velocity were assessed in this study using suspended sediment samples from Severn Estuary in controlled laboratory experiments. It was demonstrated that increased salinity with sediment concentration at low shear stress encouraged floc growth. The percentage surface area of large flocs increased with increasing sediment concentration at high salinity. However, the situation reversed at low salinity where the percentage area of large flocs decreased by nearly $77 \%$ with increasing sediment concentrations from 100 to $200 \mathrm{mg} / \mathrm{l}$.

The results clearly highlight that the effect of sediment concentration on settling velocity was controlled by the value of $\mathrm{S}$. The faster settling velocity rates occurred for the higher concentrations, as well as for low salinities of $\mathrm{S} 2.5 \mathrm{ppt}$. On the other hand, at high salinity of $20 \mathrm{ppt}$ alongside increasing $\mathrm{C}$, the situation was reversed, i.e., the lower the sediment concentration the faster the settling velocity, was found.

Future work will include applying and refining a numerical model to include the floc settling velocity relationships obtained as a function of floc size, salinity, suspended sediment concentration and turbulence.

\section{REFERENCES}

Allersma, E., A. J. Hoekstra, et al. 1967. Transport patterns in the Chao Phya Estuary.

Burban, P.-Y. et al. 1989. The flocculation of finegrained sediments in estuarine waters. Journal of Geophysical Research: Oceans 94(C6), pp. 83238330.

Dobereiner, C. and McManus, J. 1983. Turbidity maximum migration and harbour siltation in the Tay Estuary. Canadian Journal of Fisheries and Aquatic Sciences 40(SUPPL. 1), pp. 117-129.

Dyer, K. R. and Manning, A. J. 1999. Observation of the size, settling velocity and effective density of flocs, and their fractal dimensions. Journal of Sea Research 41(1-2), pp. 87-95.

Eisma, D. 1986. Flocculation and de-flocculation of suspended matter in

estuaries. Netherlands Journal of Sea Research

20(2-3), pp. 183-199

Fennessy, M. J. et al. 1994. inssev: An instrument to measure the size and settling velocity of flocs in situ. Marine Geology 117(1-4), pp. 107-117.

Flory, E. N. et al. 2004. The relationship between floc area and backscatter during a spring phytoplankton 
bloom. Deep Sea Research Part I: Oceanographic Research Papers 51(2), pp. 213-223.

Gao, G. et al. 2011. Numerical Modelling SedimentBacteria Interaction Processes in the Severn Estuary. Journal of Water Resource and Protection 3(1), pp. 22-31.

Gibbs, R. J. and Konwar, L. 1986. Coagulation and settling of Amazon River suspended sediment. Continental Shelf Research 6(1-2), pp. 127-149.

Jonas, P. J. C. and Millward, G. E. 2010. Metals and nutrients in the Severn Estuary and Bristol Channel: Contemporary inputs and distributions. Marine Pollution Bulletin 61(1-3), pp. 52-67.

Kadiri, M. B.-E., B.; Zhou, J.;Falconer,R. 2014. Water Quality Impacts of A Tidal Barrage In the Severn Estuary,UK. In: 10th ISE 2014. Trondheim, Norway.

Kirby, R. 2010. Distribution, transport and exchanges of fine sediment, with tidal power implications: Severn Estuary, UK. Marine Pollution Bulletin 61(1-3), pp. 21-36.

Krone, R. B. 1962. Flume studies of the transport of sediment in estuarial shoaling processes. Hydr. Eng. and Dan. Eng. Res. Lab. Univ. Calif.

Le Hir, P. et al. 2001. Fine sediment transport and accumulations at the mouth of the Seine estuary (France). Estuaries 24(6 B), pp. 950-963.

Lintern, D. G. 2003. Influences of flocculation on bed properties for fine-grained cohesive sediment. Oxford University.

Maggi, F. 2005. Flocculation dynamics of cohesive sediment. University of Technology, Delft.

Manning, A. J. 2001. Study of the effect of turbulence on the properties of flocculated mud University of Plymouth.

Manning, A. J. 2004. The Observed Effects of Turbulence on Estuarine Flocculation. Journal of Coastal Research, pp. 90-104.

Manning, A. J. and Dyer, K. R. 1999. A laboratory examination of floc characteristics with regard to turbulent shearing. Marine Geology 160(1-2), pp. 147-170.

Manning, A. J. et al. 2004. Flocculation measured by video based instruments in the gironde estuary during the European commission SWAMIEE project. Journal of Coastal Research (SPEC. ISS. 41), pp. 5869.

Manning, A. J. et al. 2013. Flocculation Dynamics of Mud: Sand Mixed Suspensions.

McLaren, P. et al. 1993. Sediment dynamics of the Severn Estuary and inner Bristol Channel. Journal Geological Society (London) 150(3), pp. 589-603.

MIGNIOT, C. 1968. Etude des propriétés physiques de différents sédiments très fins et de leur comportement sous des actions hydrodynamiques. . La houille blanche 7, pp. 591-620.

Mikes, D. et al. 2004. "Controlling factors in estuarine flocculation processes : experimental results with material from the Seine Estuary, Northwestern France.". Journal of coastal research 41, pp. 82-89.

Pejrup, M. et al. 1997. A fine-grained sediment budget for the Sylt-Rømø tidal basin. Helgoländer Meeresuntersuchungen 51, pp. pp. 253-268.
Pejrup, M. and Mikkelsen, O. A. 2010. Factors controlling the field settling velocity of cohesive sediment in estuaries. Estuarine, Coastal and Shelf Science 87(2), pp. 177-185.

Serra, T. and Casamitjana, X. 1998. Structure of the Aggregates During the Process of Aggregation and Breakup Under a Shear Flow. Journal of Colloid and Interface Science 206(2), pp. 505-511.

Serra, T. et al. 1997. Aggregation and Breakup of Particles in a Shear Flow. Journal of Colloid and Interface Science 187(2), pp. 466-473.

THILL, A. M., S.; GARNIER, J.M.; ESTOURNEL, C.; NAUDIN, J.J. and BOTTERO, J.Y. 2001. Evolution of particle size and concentration in the Rhône river mixing zone : influence of salt flocculation. Continental Shelf Research 21, pp. 2127-2140.

Verney, R. et al. 2009. Flocculation potential of estuarine particles: The importance of environmental factors and of the spatial and seasonal variability of suspended particulate matter. Estuaries and Coasts 32(4), pp. 678-693.

Winterwerp, J. C. 1999. On the dynamics of highconcentrated mud suspension. $\mathrm{PhD}$ Thesis, $\mathrm{PhD}$ Thesis, University of Technology, Delft.

Wollast, R. 1988. The Scheldt Estuary. W. Salomon, B.L. Bayne, E.K. Duursma, U. Förstner (Eds.), Pollution of the North Sea, an assessment, Springer-Verlag, pp. 183-193. 